\title{
Digital infrastructure of service logistics: the case of the tourism industry
}

\author{
Natalia Vasilenko \\ Department of Economics \\ St. Petersburg Mining University) \\ St. Petersburg, Russian Federation \\ nvasilenko@mail.ru
}

\author{
Tatiana Lavrova \\ Department of National Economy \\ St. Petersburg State University of \\ Economics \\ St. Petersburg, Russian Federation \\ victoriatan@inbox.ru
}

\author{
Olga Tokareva \\ Department of Foreign Language \\ St. Petersburg Mining University \\ St. Petersburg, Russian Federation \\ ov-tokareva@mail.ru
}

\begin{abstract}
The article discusses the digitization of services in the tourism industry. By applying the concept of service product to the tourism industry, the authors claim that the primary utility of a tourism product has a shifting nature and discuss the features of additional, derivative, and accompanying services as part of different types of tourism products. Logistics services in the tourism industry are considered to be one of the elements in the accompanying part of its service product. The value of the logistics support provided to tourism products is associated with the need to coordinate the efforts of tour operators, service providers involved, and the tourists themselves. The development of digital infrastructure is interpreted both as a trend connected with the development of the digital economy and as a ground for its servitization. The article highlights the advantages of a single digital infrastructure of the tourism industry and discusses its influence on different types of logistics flows. It identifies a number of areas associated with service provision which look promising in terms of their inclusion in digital infrastructure. It also contains examples of global systems and local technologies as components of the digital infrastructure in the tourism industry.
\end{abstract}

Keywords-service logistics, digital infrastructure, tourism industry, customization of tourist products, automation of service products

\section{INTRODUCTION}

One of the fastest-growing branches of the global economy is tourism. At the beginning of the XXI century, international tourism accounted for about $8 \%$ of total world exports and 30 to $35 \%$ of world trade in services. According to forecasts made by the World Tourism Organization, the number of international tourists may increase more than twofold by 2020 and amount to 1.6 billion people.

Consumer interest in different tourism services continues to increase, as evidenced by the following data on the number of international tourist arrivals in all regions of the world (Table I).
TABLE I.

THE NUMBER OF TOURIST ARRIVALS IN ALL REGIONS OF THE WORLD IN 2018 (IN MILLIONS)

\begin{tabular}{|c|l|c|c|}
\hline № & Region & $\begin{array}{c}\text { Year } \\
2018\end{array}$ & $\begin{array}{c}\text { Increase } \\
2018 / 2017 \text { (in \%) }\end{array}$ \\
\hline 1 & Europe & 713 & 6 \\
\hline 2 & Asia and the Pacific & 343 & 6 \\
\hline 3 & North and South America & 217 & 3 \\
\hline 4 & Africa & 67 & 7 \\
\hline 5 & The Middle East & 64 & 10 \\
\hline
\end{tabular}

A growth in the scale of operation in the tourism industry makes it necessary to improve resource management in this sector [1], which results in the application of logistic methods $[2,3]$ taking into consideration the accompanying functions of logistics at all stages of the development, promotion, and consumption of tourism products [4]. Under current conditions, the most important type of service logistics is information logistics, which consists of data streams that are associated with tourist traffic and the flows of products, services, and finance satisfying consumer needs [5].

In order to maintain high tourist traffic, increase the speed of service, and improve the quality of tourism services provided, digital technologies are increasingly being used, including digital platforms and mobile applications which influence consumer choices and make it possible for tourists to search for information and buy tourism products $[6,7]$.

As the environment in which today's tourism businesses operate is changing due to digitalization, one can see how companies are moving to the network format of using resources to provide services involving data exchange with counterparties $[8,9]$. This sets the trend for the development of digital infrastructure in the tourism industry.

The processual nature of the service as a market product makes it necessary to analyze the dynamic aspects of the development, promotion, and sales of service products, which, in the authors' opinion, is reflected in logistics services. In this study, digital infrastructure is understood as an open and ordered set of digital technologies which create a technological foundation for data exchange with the view of solving issues concerning production and marketing. Having assumed that the technological transformation of today's economy is a combination of technological and organizational transformations, the authors set themselves a goal to analyze the interplay between the development of 
digital infrastructure and logistics support for service products using the tourism industry as an example.

\section{MATERIALS AND METHODS}

Within this study, the concept of a service product which was substantiated in earlier works by the authors [10] was applied to the tourism industry. This concept is based on the assumption that there is a good reason to combine products and services in order to better meet the needs of clients [11]. It also relies on the features of service activities considered within the framework of service marketing [12] and service quality management.

It is possible to reveal features specific to service logistics [13] using the tourism industry as an example because tourism services are provided over a period of time and there is a need to manage the provision of resources used in these services depending on where and when a tourist is staying [14]. The high differentiation of service products in the tourism industry makes it possible to interpret the process of their development, marketing, and consumption as a set of flow processes in integrated logistics systems [15].

Digitization of activities in the tourism industry is connected with the influence of mobile communications and the Internet on the development of tourism [16, 17] against the background of a digital divide [18] and revenue growth in the host country [19]. It is also connected with digital document management [20], the use of digital marketing technologies [21,22], and the effects of digital transformation in tourism influencing productivity and management aspects $[23,24]$

\section{RESULTS}

Products offered by the tourism industry on the market have all the features of a service product by being a set of interrelated goods and services that meet the needs of tourists taking into account the two-tier structure of utility. Goods and services characterized by the secondary utility and creating a foundation for differentiating the supply of tourism are of highest importance to tourism companies willing to become more competitive.

The structure of the tourism product can be decomposed into main, additional, derivative, and accompanying components. Services of different types have different values in terms of how consumers perceive the quality of the tourism product and in terms of the division of labor between organizations in the tourism industry.

Logistics activities in the tourism industry have the properties of accompanying services. The specific features of logistics services in the tourism industry are determined by the need to synchronize tourist traffic with the flows of goods, information, and finance in order to meet the needs of those consuming tourism products, first at the stage of developing a tourism product and then at the stage of its consumption.

The development of digital infrastructure is a natural stage in the integration of technical, structural, and organizational components of systemic transformation into the economy. Digital infrastructure of logistics flows, which puts together different platforms used in tourism-related industries, leads to a decrease in transaction costs in a world where contracts are becoming more complex and the amount of information being exchanged is growing.

\section{DISCUSSION}

\section{A. Service products in tourism and their logistics support}

Today, there is no service industry which provides the consumer with a service in its pure form without connecting it to other goods or services. The opportunity of making one service product which will combine several goods and services interconnected in terms of their value for the consumer is becoming the most important source of competitive advantages for companies and organizations in the tourism industry.

The development of service products in tourism is influenced by the following features of tourism services:

- the provision of a number of services implies the consumption of certain material things which are often closely linked to these services. For example, if a tourist needs a transport service to get to a destination, they need to buy a railway or airplane ticket. If a tourist needs to use some online booking services, they will need a special device (a smartphone, tablet, etc.) and a SIM card;

- the main service (accommodation, food, and transportation) is accompanied by the opportunity to use other goods and services. For instance, airplane passengers can buy duty-free goods on board and tourists staying at hotels can book tickets for concerts using hotel services;

- almost any service in the tourism industry is accompanied by online financial operations, such as booking and paying for a tour, checking in for a flight, booking an excursion, etc.

From the consumer's point of view, the following types of utility can be distinguished in the service product:

- basic (primary) utility, which correlates with meeting the need which spurred the customer to purchase a particular tourism product;

- additional (secondary) utility, which enhances the utility of a product in the customer's eyes. It can be objective (functional), for example, a decrease in time spent waiting, or subjective (emotional), as is the case with a hotel upgrade.

A key role in the development of a service product and its logistics support in the tourism industry is played by the shifting nature of the primary utility. The shifting nature means that, firstly, different goods and services will or will not have basic utility depending on different tourists, and secondly, consumer preferences can change under the influence of various factors. There is therefore an important attribute of the tourism product in terms of its quality and customer satisfaction, which is interdependence between all components.

There is another important attribute of the service product, which is interdependence between all its parts. The results of studies in the field of assessing the quality of services confirm that the perception of a service product in the customer's eyes 
depends on how high each of its components scores in the process of consumption.

Competition between services having primary utility has already led to a situation where further improvement of their quality depends on investing in product and technology innovations. This is why opportunities for gaining competitive advantages associated with the way the consumer perceives the utility of a service product lie in the additional components of the product, which differ depending on the service company. In other words, they lie in secondary utility.

In order to understand what a service product is made of in terms of secondary utility, it is worth distinguishing between three types of services:

- additional services;

- derivative services;

- accompanying services.

Additional services can be divided into two groups:

- compulsory services, which are provided by companies in the tourism industry because the lack or low quality of these services negatively influence consumer opinion;

- non-compulsory services, which enhance consumer perception and make the company stand out from its competitors.

Derivative services include services which are provided due to the rules for the provision of services preceding derivative ones in accordance with their nature and purpose. The need for derivative services arises when the consumer has the right to use the main service. Along with this right goes the right to make use of different derivative services, both commercial and those already included in the price of the main service. For example, when staying at a hotel, derivative services provided to the tourist are food services in different forms (breakfast; breakfast and lunch; breakfast and dinner; full board; all inclusive).

The number of compulsory and non-compulsory additional services determines the category of the place where tourists stay and the set of derivative services determines the level of service chosen by the tourist.

Accompanying services cannot be found on the market as independent items. They are provided to tourists as free supplements because their price is included by the seller in the market price of the service product instead of being paid by the customer separately. Accompanying services in the tourism industry take different forms (information, financial, transfer, visa, and insurance services) and are provided at different stages of service provision (Table II).

TABLE II. STAGES OF PROVIDING ACCOMPANYING SERVICES IN TOURISM

\begin{tabular}{|l|l|}
\hline $\begin{array}{c}\text { The name of } \\
\text { the stage }\end{array}$ & \multicolumn{1}{|c|}{ Types of services } \\
\hline Preparatory & $\begin{array}{l}\text { Marketing research on tourism services. } \\
\text { Development including customized ones. Information } \\
\text { inclucts, }\end{array}$ \\
& $\begin{array}{l}\text { support. tourism products } \\
\text { Sales of tourism products, paperwork, and payment } \\
\text { services. }\end{array}$ \\
\hline
\end{tabular}

\begin{tabular}{|l|l|}
\hline Main & $\begin{array}{l}\text { Transport and accompanying services on the way to } \\
\text { and from the destination. Accommodation services. } \\
\text { Excursion arrangements other } \\
\text { types of arrangements. } \\
\text { Solving customers' problems in emergency situations. }\end{array}$ \\
\hline Supporting & $\begin{array}{l}\text { Receiving and processing feedback. } \\
\text { Developing and offering loyalty programs, individual } \\
\text { discounts, and club membership cards. } \\
\text { Sharing information about promotional events, etc. }\end{array}$ \\
\hline
\end{tabular}

As a rule, both basic and additional utility is created and offered by a group of participants in the tourism market rather than one company. For example, the tourism product provided by one country consists of integration services provided by tour operators and travel agencies, transport, accommodation, and sightseeing services, services in other sectors such as finance, banking, security, and insurance, goods for tourists (souvenirs, food items, etc.), geographic and climatic resources, landmarks, and attractions. It should be noted that one and the same tourism product can be valuable from the sightseeing perspective in one situation and from the leisure perspective in another. This attribute makes it possible to combine the model of a product with basic and additional utility with the model of creating value chains in the industry.

The division of services into basic, additional, derivative, and accompanying ones can be used by tour operators with the aim of optimizing the package of services when developing tours which will be provided to tourists as a single product. If it is a package tour which includes all kinds of services regarding food, accommodation, sightseeing, transportation, healthcare, and others, all tourism services that the customer needs are included in the package during the planning process as basic ones. For instance, they may include visits to medical centers with tourists accompanied by an interpreter. Inclusive tours offer a range of the most popular basic and derivative services, and, as a rule, take the form of a trip with the itinerary, dates, destinations, and services specified in advance and sold as a single product at a total price. Consumers buy additional services only when they need them, which usually reduces the cost of the tour.

In both cases, tourists are provided with accompanying services, but the forms of their provision may be different due to the division of labor in the logistics system. For example, a visa can be obtained simultaneously with the purchase of a tour and be part of the tourism product, or it can be obtained by a tourist after applying to a consulate or using services provided by an intermediary organization.

One of the types of support provided to service products is logistics support. Logistics is the management of objects which, when static, form resources and, when dynamic, become flows. In addition to resource flows, service logistics is aimed at managing customer flows. In the tourism industry, its function is to synchronize transport operations, as well as corresponding material and staff flows, in the place where tourism services are produced and consumed.

The importance of logistics support to tourism products stems from the fact that the efficiency of tourism services is directly dependent on coordination between all participants in the service: tour operators, service providers, and tourists themselves. The institutionalization of logistics services in tourism is carried out by integrating previously unrelated 
types of services into a single cycle of customer service and, as a result of the growing complexity of contractual relations, by separating it into an individual line of service activities which is quickly evolving. The result of providing logistics support is the integration of functional areas related to the movement of resources into a single resource flow system of the service industry.

Service flows in tourism can be divided by the position they occupy in service support into:

- pre-sales flows, which are connected with the development and promotion of tourism products and cover market research, including the development of new products and services, experimental evaluation of a new tourism product, drafting papers and signing contracts with the participants in the logistics chain, personnel training in promoting tourism products, marketing and sales of new tourism products;

- post-sales flows, which are connected with performing logistics operations in the provision of services that are part of the tourism product.

\section{B. Digital infrastructure for logistics support}

The emergence of the digital economy is a process of systemic transformation in which two interrelated components can be distinguished:

- technical component, which includes an ordered set of tangible and intangible resources, i.e. a combination of technologies and equipment;

- organizational component, which is a combination of methods, forms, and mechanisms responsible for economic efficiency that are used to put together tangible and intangible resources including risks associated with the opportunistic behavior of participants in organizational relationships.

The first component lays the groundwork for the second one. The technological transition in the form of digitalization has led to changes in the forms and mechanisms of interaction between economic agents. The industrial economy is characterized by the division of the process of creating goods into separate production functions. These functions were carried out using a system of machinery and equipment in order to process natural resources with a gradual replacement of manual labor with technology. Machinery acted as an intermediary between the laborer and the process of creating material goods, and its priority manifested itself in the fact that the worker adapted to the machine and also ensured and maintained its operation. The main form of economic organization in such conditions was a large production or processing company.

In the digital economy, not only the main but also auxiliary service functions and processes are becoming more universal. As part of the spread of digital technologies and platforms, service functions and processes become more efficient as they are performed beyond the limits of one company responsible for the main production process. The provision of such services to many partners creates a foundation for improving their quality through specialization and the division of labor in the service sector. As a result, the development of the digital economy is characterized by a seismic shift from the technical component to the organizational one. At present, it manifests itself in the separation of large companies into individual services using digital technologies and platforms.

The fact that there is a large number of tourism companies, which are usually quite small, along with the differentiation of the tourism products they provide, leads to an increase in transaction costs due to an increase in the number of contracts and the amount of information. This situation can be changed if digital technologies become standardized and are used as a foundation for digital infrastructure.

\section{Digital infrastructure in the tourism industry is a}

combination of technologies and products created with the help of these technologies which make it possible to collect, transmit, and store data in a safe way using information systems in order to meet the needs of consumers, tourism organizations, and regulatory bodies operating in this area.

Since the process of providing a service product in the tourism industry was previously described as a combination of synchronized logistics flows, it can be concluded that the digital infrastructure of service logistics is a foundation for the digital infrastructure of the tourism industry as a whole.

There are several advantages of digital infrastructure over a set of separate digital platforms. Among them is the integrity of a network used for information transfer, as well as flexibility, scalability, ease of integrating different functional platforms, standardized management procedures, and a decrease in operating costs.

Digital infrastructure in the tourism industry influences logistics flows in different ways depending on their types (Table III).

TABLE III. DIGITAL INFRASTRUCTURE AND LOGISTICS FLOWS IN THE TOURISM INDUSTRY

\begin{tabular}{|l|l|l|}
\hline \multicolumn{1}{|c|}{ Flow type } & \multicolumn{1}{|c|}{ Function } & \multicolumn{1}{c|}{ Influence } \\
\hline Tourist traffic & $\begin{array}{l}\text { Delivering consumers } \\
\text { to the place where } \\
\text { they will be provided } \\
\text { with services }\end{array}$ & $\begin{array}{l}\text { Provision of } \\
\text { information about } \\
\text { products and services } \\
\text { in order to expand the } \\
\text { market for tourism } \\
\text { products }\end{array}$ \\
\hline Resource flow & $\begin{array}{l}\text { Functional support for } \\
\text { service provision }\end{array}$ & $\begin{array}{l}\text { Coordination of } \\
\text { activities with service } \\
\text { providers in order to } \\
\text { synchronize resources } \\
\text { in time and space }\end{array}$ \\
\hline Information flow & $\begin{array}{l}\text { Information exchange } \\
\text { between the suppliers } \\
\text { and consumers of the } \\
\text { tourism product }\end{array}$ & $\begin{array}{l}\text { Transition to } \\
\text { electronic document } \\
\text { management, tracking } \\
\text { the movement of } \\
\text { service product } \\
\text { components to the } \\
\text { buyer, timely reaction } \\
\text { to problems }\end{array}$ \\
\hline Financial flow & $\begin{array}{l}\text { Cash movement } \\
\text { between the suppliers } \\
\text { and consumers of the } \\
\text { tourism product }\end{array}$ & $\begin{array}{l}\text { Control over financial } \\
\text { flows, increase in the } \\
\text { speed of transactions } \\
\text { between parties, } \\
\text { increase in the speed } \\
\text { of paying taxes }\end{array}$ \\
\hline
\end{tabular}


In order to ensure that the activities of service providers in the tourism industry are coordinated, digital infrastructure should include a number of platforms covering such industries as transportation, hospitality, catering, leisure, culture, entertainment, sports, healthcare, edutainment, telecommunications, and multimedia.

The most important component of the digital infrastructure of service logistics in the tourism industry is a global distribution system (GDS). The largest systems of this kind are GALILEO (1987, headquartered in Parsippany, New Jersey, USA), SABRE (1964, headquartered in Tulsa, Oklahoma, USA), WORLDSPAN (1991, headquartered in Atlanta, Georgia, USA), AMADEUS (1987, headquartered in Madrid, Spain), and others.

Examples of local digital infrastructure elements are digital technologies used in the industry in order to improve the quality of services provided to guests:

- facial recognition systems used at check-in and checkout stages as well as in service provision;

- radio frequency identification (RFID) door locks that provide access to rooms and other spaces in a hotel with the help of a mobile phone eliminating the use of keys;

- voice and gesture controlled systems in hotel rooms;

- an interactive television system, for example, IPTV;

- high-speed wireless Internet access;

- a power management system based on the Smart Building concept;

- a service management system and the use of robots for cleaning rooms, for example.

The use of the digital infrastructure of service logistics lets companies in the tourism industry:

- develop tourism products which will be more relevant, attractive, and affordable, and shorten the periods of their development and promotion;

- create and use a single automated system for accounting, managing the movement of tourism products, and managing financial and information flows in order to reduce operating costs;

- reduce the volume of documentation and the number of errors in documents;

- optimize staffing without sacrificing the speed and quality of service.

\section{CONCLUSIONS}

The systemic transformation of the economy happening today is reflected in two interdependent trends: digitalization (the technical component) and servitization (the organizational component). When analyzed in terms of their structure and the resources they require, service products appear as static models aimed at meeting the needs of modern consumers. The analysis of how service products are developed, promoted, and consumed requires the transition to logistics flows as a dynamic form of presenting service products. It should be expected that as the service industry is expanding, the value of service logistics will increase.

The servitization of the economy is accompanied by an increase in the number of relatively small companies which interact with each other while customers consume goods and services which are part of a service product. The higher the degree of digital integration, the more pronounced are such effects as resource conservation, including economies of time and a decrease in information costs. All the things said above show that it is natural for the development of digital infrastructure to serve as a foundation for the servitization of the economy and for service logistics to be a dynamic form of the consumption of service products.

The tourism industry is an industry where the level of development of logistics makes it possible to analyze all the features of the static and dynamic presentation of the products it creates, and the level of digitalization makes it possible to give examples of how both global and local elements of the digital infrastructure are used.

The authors suppose that further research can be done into how the digital infrastructure of service logistics is developed in other service industries as well as into identifying factors which guide the evolution of technologies and platforms that are part of the digital infrastructure.

\section{REFERENCES}

[1] E. V. Arbatskaya, "Logistics Innovation in the Modern Management of Tourism Enterprises“, Bulletin of the Faculty of Man. SPbGEU, Vol. 11, pp. 353-358, 2017.

[2] T. Skorobogatova, "Tourism Logistics in Focus of New Logistics Directions", Services in Russia and abroad, Vol. 10, Is. 1 (62), pp. $124135,2016$.

[3] H. U. R. Khan, K. Zaman, and A. M. Shoukry, "Tourism logistics management through financial and regulatory measures: evidence from a panel of countries“, Asia Pacific J. of Tourism Res., Vol. 24, Is. 5, 4, pp. 443-458, May 2019.

[4] N. N. Muravyova, A. D. Murzin, and M. A. Chernyshov, "Trends of Development of Logistical Services in the Tourist Industry“, J "U". Economy. Control. Financial, Is. 1, pp. 91-101, 2016.

[5] M. N. Zaitseva, "Information Logistics in the Management of Tourist Enterprise", Economics, Management, Law: Problems of Establishing and Transformation. Dubai, UAE: Al Ghurair Printing and Publishing LLC. 2016. pp. 319-322.

[6] P. Constantinides, O. Henfridsson, and G. G. Parker, "Platforms and infrastructures in the digital age“, Inf. S. Research, Vol. 29, Is. 2, pp. 381-400, 1 June 2018

[7] Z. Xiang, Z. Schwarts, and J.H. Gerdes, "What can big data and text analytics tell us about hotel guest experience and satisfaction?“, Int. J. of Hospitality Man., Vol. 44, pp. 120-130, January 2015.

[8] B. Keller, M. Möhring, and M. Toni, "Data-centered platforms in tourism: Advantages and challenges for digital enterprise architecture", Lecture Notes in Business Inf. Processing, Vol. 263, pp. 299-310, 1 January 2017.

[9] M. Gioconda, D.V. Pasquale, and P. Giuseppina, "A network approach for smart tourism destination: Evidences from a digital local experience", Proceedings of the 30th International Business Information Management Association Conference, IBIMA 2017 Vision 2020: Sustainable Economic development, Innovation Management, and Global Growth. Vol. 2017, pp. 4863-4878. January 2017.

[10] N. V. Vasilenko and A. J. Linkov, "Customization of the Telecommunication Market Based on the Application of the Concept of Service Products", Telecommunication Networks - Trends and Developments, Mohammad Abdul Matin, IntechOpen, November 2018, 2018DOI: 10.5772/intechopen.79030 
[11] $\mathrm{Ph}$. Kotler, G. Armstrong and J. Saunders Principles of marketing. 5rd Europ. ed. London : Financial times Prentice Hall, 2008.

[12] Ch. Lovelock and W. J. Jochen. Services Marketing: People, Technology, Strategy. USA: World Scientific Publishing Co. Inc.,2016.

[13] O. N. Lipatova, E. V. Polyanskaya, and E. R. Arslanova, "Features of Logistics of the Tertiary Sector of Economics“, Vestnik of Astrakhan State Technical University. Series: Ec., Is. 4. pp. 132-136, 2017.

[14] S. Muhcină and V. Popovici, "Logistics and supply chain managemen in tourism", Amfiteatru Economic, Vol. 10, Is. 24, pp. 122-132, June 2008

[15] N. A. Malshina, "Management Stream Processes in Service and Tourism Industry in the Development of E-Commercialization of the Economy“, Bulletin of the Volga Institute of Man., Is. 2 (23), pp. $166171,2010$.

[16] O. Adeola and O. Evans, "Digital tourism: mobile phones, internet and tourism in Africa“, Tourism Recreation Res., Vol. 44, Is. 2, pp. 190202, April 2019.

[17] M. E. Styvén and Å. Wallström, "Benefits and barriers for the use of digital channels among small tourism companies“, Scandinavian J. of Hospitality and Tourism, Vol. 19, Is. 1, pp. 27-46, January 2019.

[18] L. M. Ruiz-Gómez, J. Navío-Marco, and L. F. Rodríguez-Hevía, "Dynamics of digital tourism's consumers in the EU", Inf. Technology and Tourism, Vol. 20, Is. 1-4, pp. 59-81, December 2018

[19] M. Watkins, S. Ziyadin, and A. Imatayeva, "Digital tourism as a key factor in the development of the economy“, Econ. Annals-XXI, Vol. 169 , Is. $1-2$, pp. 40-45, July 2018
[20] E. V. Stelnik, Y. A. Kiyashko, and P. I. Lysikov, "Information technology in the digital document management in the tourism industry as a perspective tool in increasing effectiveness of a tourist enterprise", IOP Conference Series: Materials Science and Engineering, Vol. 483, Is. 1, March 2019.

[21] G. Gupta, "Inclusive use of digital marketing in tourism industry", Advances in Intelligent Sys. and Comp., Vol. 862, pp. 411-419, 2019.

[22] Z. Koto, and Y. Bandung, "Interactive Digital Signage architecture to improve user interaction on tourism information services", Int. Symposium on Electronics and Smart Devices, ISESD 201624, pp. 380-385, March 2017.

[23] A. Fereidouni, and M. Kawa, "Dark Side of Digital Transformation in Tourism", Lecture Notes in Computer Science, Vol. 11432 LNAI, pp. 510-518, 2019.

[24] L. P. Voronkova, "Virtual Tourism: On the Way to the Digital Economy", IOP Conference Series: Materials Science and Engineering, Vol. 463, Is. 4, 31 December 2018. 